\title{
PENINGKATAN KUALITAS AIR ASAM TAMBANG MENGGUNAKAN ZEOLIT DAN BAKTERI SEBAGAI MEDIA ADSORPSI DENGAN METODE SEDIMENTASI SECARA ANAEROB DI PT BUKIT ASAM, Tbk. TANJUNG ENIM, SUMATERA SELATAN
}

\author{
IMPROVING THE QUALITY OF MINING ACID WATER USING ZEOLITE AND \\ BACTERIA AS ADSORPTION MEDIA WITH ANAEROBIC SEDIMENTATION \\ METHOD AT PT BUKIT ASAM, Tbk. TANJUNG ENIM, SOUTH SUMATERA
}

\author{
Dian Kurnia Sari ${ }^{1)}$, Euis Kusniawati ${ }^{2)}$, Renta Srimardani ${ }^{3)}$ \\ ${ }^{1,2,3)}$ Program Studi Teknik Analisis Laboratorium Migas Politeknik Akamigas Palembang, 30257, Indonesia \\ Corresponding Author E-mail: dian.212@gmail.com,euis_kusniawati@yahoo.com dan rentasrimardani@gmail.com
}

\begin{abstract}
Acid mine drainage is water with low $\mathrm{pH}$ and has high metal solubility. In general, this water will be flowed to the environment, so the processing is very important to note. This research step covers the activation of natural zeolites and bacteria (sulfate reducing bacteria and waste decomposing bacteria). Next, each material was applied as an adsorption medium on the sample which was done using anaeorobic sedimentation method. The results of research conducted after five days of treatment showed improvement on the quality of acid mine drainage, in which each treatment gave different impacts on every sample test parameter. From the research results using five different treatments, it was found out that the treatment using combination of sulfate reducing bacteria and zeolite was the most effective to use. The results obtained were initial $\mathrm{pH}$ value of 2.98 increased to 5.72 , TSS value from $3 \mathrm{mg} / \mathrm{l}$ to $1 \mathrm{mg} / \mathrm{l}$, $\mathrm{Fe}$ metal concentration from $1.7664 \mathrm{mg} / \mathrm{l}$ to $0.1924 \mathrm{mg} / \mathrm{l}$ (sedimentation efficiency was $89.11 \%$ ), and metal content of Mn from 9,4931 mg/l to 5,2813 mg/l (sedimentation efficiency was 44.37\%).

Keywords: Acid mine drainage, Zeolite, Sulfate Reducing Bacteria, Waste Decomposing Bacteria, Adsorption.
\end{abstract}

\begin{abstract}
Abstrak: Air asam tambang merupakan air dengan pH rendah dan memiliki kelarutan logam yang tinggi, pada umumnya air tersebut akan dialirkan kelingkungan sehingga dalam pengolahannya sangat perlu diperhatikan. Tahap penelitian ini meliputi aktivasi zeolit alam dan bakteri (bakteri pereduksi sulfat dan bakteri pengurai limbah), selanjutnya pengaplikasian masing-masing bahan sebagai media adsorpsi terhadap sampel yang dilakukan dengan metode sedimentasi secara anaerob. Hasil penelitian yang dilakukan setelah lima hari treatment menunjukkan adanya peningkatan kualitas air asam tambang, dimana masing-masing treatment memberikan pengaruh berbeda pada setiap parameter uji sampel. Dari hasil penelitian menggunakan lima macam treatment dapat diketahui bahwa treatment menggunakan kombinasi bakteri pereduksi sulfat dan zeolit paling efektif untuk digunakan. Adapun hasilnya, yaitu nilai pH awal 2,98 menjadi 5,72, nilai TSS dari $3 \mathrm{mg} / \mathrm{l}$ menjadi $1 \mathrm{mg} / \mathrm{l}$, konsentrasi logam Fe dari 1,7664 mg/l menjadi 0,1924 mg/l (efisiensi pengendapan sebesar 89,11\%), dan kandungan logam Mn dari 9,4931 mg/l menjadi 5,2813 mg/l (efisiensi pengendapan sebesar 44,37\%).
\end{abstract}

Kata Kunci : Air Asam Tambang, Zeolit, Bakteri Pereduksi Sulfat, Bakteri Pengurai Limbah, Adsorpsi

\section{PENDAHULUAN}

\subsection{Latar Belakang}

Air asam tambang merupakan air dengan $\mathrm{pH}$ rendah dan memiliki kelarutan logam yang sangat tinggi, apabila air asam tambang ini sudah terbentuk sulit untuk mencegahnya, umumnya air tersebut akan dialirkan kelingkungan sehingga dalam pengolahannya sangat perlu diperhatikan.

Upaya Untuk mengurangi dampak negatif air asam tambang ini telah dilakukan melalui dua cara, yaitu secara pasif treatment dan active treatment. Pengolahan secara pasif treatment salah satunya adalah melalui lahan basah buatan sebagai alternatif pengelolaan air asam tambang karena biayanya lebih murah, dan ramah lingkungan. Akan tetapi dalam segi waktu pengolahan secara pasive treatment kurang efektif karena sistem pengolahan jangka panjang atau memanfaatkan unsur alam. Sedangkan salah satu pengolahan active treatment adalah melalui penambahan bahan kimia, bersifat alkali seperti kapur, dan larutan $\mathrm{NaOH}$. Pengelolaan air asam tambang dengan sistem ini dinilai efektif dapat menaikkan $\mathrm{pH}$ air dan menurunkan kadar logam $\mathrm{Fe}$, logam Mn serta TSS. Tetapi dengan sistem ini harus dilakukan penambahan bahan kimia secara 
terus menerus dan juga memerlukan perawatan peralatan operasional dan pemeliharaan (Defriansyah, 2018).

Cara lain yang diharapkan bisa memberikan keuntungan lebih besar adalah dengan memanfaatkan bakteri pereduksi sulfat dan batuan zeolit alam untuk meningkatkan $\mathrm{pH}$ dan mengimobilisasi logam-logam berbahaya. Keuntungan penggunaan bakteri ini salah satunya bakteri tersebut dapat diisolasi atau dibuat dari kolam pengendapan lumpur. Keuntungan dari batuan zeolit alam ini, yaitu sifatnya sebagai absorben yang bagus karena memiliki pori-pori yang baik, batuan ini juga banyak terdapat di Indonesia dan harganya yang relatif murah.

\subsection{Ruang Lingkup}

Ruang lingkup dalam penelitian ini adalah pengolahan air asam tambang batubara menggunakan bakteri pereduksi sulfat, bakteri pengurai limbah, dan batuan zeolit dalam parameter uji $\mathrm{pH}$, TSS, kadar logam Fe dan kadar logam Mn.

\subsection{Tujuan Penelitian}

Tujuan dalam penelitian ini adalah :

1. Mengetahui perbandingan hasil $\mathrm{pH}$, TSS, kadar logam $\mathrm{Fe}$ dan kadar logam Mn di dalam air asam tambang sebelum dan sesudah pengolahan menggunakan bakteri dan zeolit.

2. Mengetahui tingkat kinerja masing-masing dari bakteri dan zeolit dalam pengolahan air asam tambang baik pengolahan menggunakan bakteri, zeolit maupun kombinasi keduanya.

3. Mengetahui pilihan treatment yang paling efektif untuk digunakan diantara lima 4. macam treatment yang telah dilakukan.

\subsection{Manfaat Penelitian}

Dengan penelitian ini diharapkan dapat memberikan manfaat sebagai berikut :

1. Diperoleh kualitas air asam tambang yang lebih baik setelah diberi perlakuan menggunakan zeolit dan bakteri.
2. Dapat mengetahui tingkat kinerja dan pengaruh masing - masing perlakuan terhadap kualitas air asam tambang.

Diketahuinya treatment yang paling efektif untuk digunakan diantara lima macam treatment yang telah dilakukan.

\section{TEORI DASAR}

\subsection{Air Asam Tambang}

Menurut Rudy (2012), Air asam tambang adalah air yang terbentuk akibat dari kegiatan penambangan dengan $\mathrm{pH}$ rendah $(\mathrm{pH}<6)$ sebagai dampak dibukanya suatu potensi keasaman batuan, sehingga menimbulkan permasalahan terhadap kualitas air dan tanah, dimana pembentukannya dipengaruhi oleh tiga faktor utama yaitu air, oksigen, dan batuan yang mengandung mineral-mineral sulfida.

\subsection{Pembentukan dan Karakteristik Air Asam Tambang}

Proses pembentukan air asam tambang dapat berlangsung dengan cepat, tetapi dapat juga berlangsung sekian lama setelah mineral sulfida terbuka. Pembentukan air asam tambang ditemukan baik di lokasi pertambangan dengan tingkat curah hujan yang tinggi maupun pada daerah yang relatif kering.

Berikut adalah reaksi umum pembentukan air asam tambang :

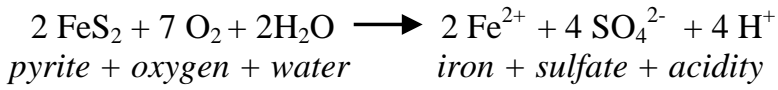

Air asam tambang dicirikan oleh kandungan sulfat yang tinggi $(>1.000 \mathrm{mg} / \mathrm{l})$, kandungan besi dan alumanium $(>100 \mathrm{mg} / \mathrm{l})$ dan konsentrasi tembaga, kromium, nikel, timbal, dan zink lebih dari $10 \mathrm{mg} / \mathrm{l}$ (Lottermoser, 2010). Kandungan $\mathrm{Fe}$ dan $\mathrm{Al}$ terlarut umumnya lebih tinggi dibandingkan dengan unsur lainnya.

\subsection{Sumber Air Asam Tambang}

Air asam tambang dapat terjadi pada kegiatan penambangan, keadaan ini terjadi karena unsur sulfur yang terdapat di dalam batuan teroksidasi secara alamiah didukung 
juga dengan curah hujan yang tinggi semakin mempercepat perubahan oksida sulfur menjadi asam (Rudy, 2012). Sumber-sumber air asam tambang antara lain berasal dari kegiatankegiatan berikut :

1. Air dari tambang terbuka

2. Air dari unit pengolahan batuan buangan

3. Air dari lokasi penimbunan batuan

4. Air dari tempat penimbunan bahan galian

\subsection{Faktor-faktor yang Mempengaruhi Kualitas Air Asam Tambang \\ 1. $\mathrm{pH}$ (Derajat Keasaman)}

Nilai $\mathrm{pH}$ menunjukkan derajat keasaman dalam air dinyatakan sebagai logaritma konsentrasi ion $\mathrm{H}^{+}$. Larutan bersifat asam bila nilai $\mathrm{pH}<7$ dan larutan bersifat basa bila nilai $\mathrm{pH}>7$. Nilai $\mathrm{pH}$ yang normal untuk air adalah netral yaitu $\mathrm{pH}=7$, dengan toleransi \pm 1 . Sehingga air dengan $\mathrm{pH}$ yang baik adalah air yang memiliki nilai $\mathrm{pH}$ 6-8.

\section{TSS (Total Suspended Solid)}

TSS merupakan padatan yang dapat langsung mengendap dalam air akibat pengaruh gaya gravitasi. Padatan yang mengendap tersebut terdiri dari partikelpartikel padatan yang mempunyai ukuran relatif besar dan berat sehingga dapat mengendap dengan sendirinya. Endapan yang terdapat di dalam air terbentuk sebagai akibat dari erosi, lumpur dan pasir.

3. Besi (Fe)

Besi merupakan elemen pertama golongan VIII B dalam tabel periodik. Besi memiliki nomor atom 26, berat atom 55,85 gram $/ \mathrm{mol}$. Besi yang murni adalah logam bewarna putih perak yang kukuh. Jarang terdapat besi komersial yang murni dan biasanya besi mengandung sejumlah kecil karbida, silusida, fosfida, sulfida dan besi sedikit grafit. Zat-zat pencemar itu memainkan peran penting dalam kekuatan struktur besi. Asam klorida encer atau pekat dan asam sulfat encer dapat melarutkan besi, dan akan menghasilkan garam-garam besi(II) serta gas hidrogen.

4. Mangan (Mn)
Mangan merupakan elemen pertama golongan VII B dalam tabel periodik. Mangan memiliki nomor atom 25 dan berat atom 54,94 gram/mol. Mangan adalah logam putih abuabu yang penampilannya serupa besi tuang, bereaksi dengan air hangat membentuk Mangan (II) Hidroksida yang putih dan hidrogen. Air yang berasal dari sumber tambang asam dapat mengandung mangan terlarut dengan konsentrasi $\pm 1 \mathrm{mg} / \mathrm{l}$. Pada $\mathrm{pH}$ yang agak tinggi kondisi aerob terbentuk mangan yang tidak larut seperti $\mathrm{MnO}_{2}$ meskipun oksidasi dari $\mathrm{Mn}^{2+}$ itu berjalan relatif lambat (Febrina, 2014).

Tabel 2.1 Baku Mutu Air Limbah

\begin{tabular}{|c|c|c|}
\hline Parameter & Satuan & Kadar Maksimum \\
\hline $\mathrm{pH}$ & - & $6-9$ \\
\hline Residu Tersuspensi & $\mathrm{mg} / \mathrm{l}$ & 400 \\
\hline Besi $(\mathrm{Fe})$ Total & $\mathrm{mg} / \mathrm{l}$ & 7 \\
\hline Mangan (Mn) Total & $\mathrm{mg} / \mathrm{l}$ & 4 \\
\hline
\end{tabular}

\subsection{Dampak Air Asam Tambang}

Terbentuknya air asam tambang di lokasi penambangan akan menimbulkan dampak negatif terhadap lingkungan. Dampak negatif dari air asam tambang tersebut antara lain:

1. Bagi masyarakat di sekitar wilayah tambang

Logam berat yang terkandung dalam air asam tambang bersifat toksik (beracun) bagi makhluk hidup. Di dalam tubuh manusia, tembaga $(\mathrm{Cu})$ dapat mengakibatkan depresi, mempengaruhi fungsi hati dan ginjal serta menimbulkan gangguan pada pembuluh darah.

2. Bagi biota perairan

Dampak negatif untuk biota perairan adalah terjadinya perubahan keanekaragaman biota perairan seperti plankton dan benthos, kehadiran benthos dalam suatu perairan dapat digunakan sebagai indikator kualitas perairan.

3. Bagi kualitas air permukaan

Terbentuknya air asam tambang hasil oksidasi pirit akan menyebabkan 
menurunnya kulitas air permukaan. Parameter kulitas air yang mengalami perubahan diantaranya $\mathrm{pH}$, padatan terlarut, sulfat, besi dan mangan.

\section{Kualitas tanah}

Logam berat seperti besi, tembaga seng terkandung dalam tanah yang asamnya banyak, yang pada dasarnya merupakan unsur hara mikro yang dibutuhkan tanaman, sementara unsur hara makro yang dibutuhkan tanaman seperti forfor, magnesium, kalsium sangat kurang. Akibatnya keracunan pada tanaman karena kelebihan unsur hara mikro, ini ditandai dengan membusuknya akar tanaman sehingga tanaman menjadi layu dan akhirnya mati.

\subsection{Zeolit}

Zeolit adalah senyawa zat kimia alumino-silikat berhidrat dengan kation natrium, kalium dan barium. Secara umum, zeolit memiliki molekular struktur yang unik, dimana atom silikon dikelilingi oleh empat atom oksigen sehingga membentuk semacam jaringan dengan pola yang teratur. Dibeberapa tempat di jaringan ini, atom silikon digantikan dengan atom alumanium, yang hanya terkoordinasi dengan tiga atom oksigen. Atom alumanium ini hanya memiliki muatan $3^{+}$, sedangkan silikon sendiri memiliki muatan $4^{+}$. Keberadaan atom alumanium ini secara keseluruhan akan menyebabkan zeolit memiliki muatan negatif, muatan negatif inilah yang menyebabkan zeolit mampu mengikat kation.

Zeolit mempunyai sifat dehidrasi (melepaskan molekul $\mathrm{H}_{2} \mathrm{O}$ ) apabila dipanaskan. Pada umumnya struktur kerangka zeolit akan menyusut, tetapi kerangka dasarnya tidak mengalami perubahan secara nyata. Disini molekul $\mathrm{H}_{2} \mathrm{O}$ seolah-olah mempunyai posisi yang spesifik dan dapat dikeluarkan secara reversibel. Sifat zeolit sebagai adsorben dan penyaring molekul, dimungkinkan karena struktur zeolit yang berongga, sehingga zeolit mampu menyerap sejumlah besar molekul yang berukuran lebih kecil atau sesuai dengan ukuran rongganya.
Selain itu kristal zeolit yang telah terdehidrasi merupakan adsorben yang selektif dan mempunyai efektivitas adsorpsi yang tinggi (Sinly, 2007).

Zeolit merupakan mineral yang banyak dijumpai di Indonesia dan memiliki banyak sifat salah satunya sebagai adsorben logam. Logam-logam hasil sisa industri yang dibuang ke alam kadar yang melampaui batas limbah dapat merusak ekosistem. Zeolit dapat digunakan untuk mengatasi logam-logam tersebut dengan mengadsorpsinya. Zeolit memiliki banyak jenis, salah satunya adalah modernit. Zeolit alam perlu diaktivasi atau dimodifikasi terlebih dahulu agar kemampuannya optimum untuk mengadsorpsi limbah logam.

\subsection{Bakteri}

Bakteri terdiri dari berbagai jenis ada yang sifatnya merugikan dan ada pula yang menguntungkan, dalam penelitian ini bakteri yang akan digunakan, yaitu :

1. Bakteri pereduksi sulfat (BPS)

Bakteri pereduksi sulfat merupakan bakteri obligat anaerob yang menggunakan $\mathrm{H}_{2}$ sebagai donor elektron. BPS dapat mereduksi sulfat pada kondisi anaerob menjadi sulfide. Selanjutnya $\mathrm{H}_{2} \mathrm{~S}$ yang dihasilkan dapat mengendapkan logam-logam yang bersifat piruvat (Hanafiah, 2009).

Bakteri pereduksi sulfat (BPS) terdiri dari dua genus, yaitu Desulfovibrio dan Desulfotomaculum. Desulfovibrio hidup pada kisaran pH 6 sampai netral, sedangkan Desulfotomaculum merupakan kelompok BPS yang termofil (menyukai suhu yang tinggi).

2. Bakteri Pengurai Limbah

Bakteri pengurai merupakan kelompok bakteri yang mampu mendekomposisi organisme lain yang telah mati menjadi unsurunsur penyusunnya yang akan kembali ke lingkungan. Beberapa jenis bakteri pengurai mampu membentuk senyawa $\mathrm{NH}_{3}$ dari proses dekomposisi biomolekul protein melaui proses amonifikasi yang kemudian akan masuk ke dalam siklus nitrogen dan selanjutnya digunakan oleh organisme lain. 
Pada penelitian ini menggunakan salah satu jenis bakteri pengurai limbah, yaitu bakteri Nitrobacter, bakteri ini merupakan bakteri nitrifikasi karena ia dapat mengubah nitrit menjadi nitrat. Nitrobacter menggunakan energi dari oksidasi ion nitrit $\left(\mathrm{NO}^{2-}\right)$ menjadi ion nitrat $\left(\mathrm{NO}^{3-}\right)$ untuk memenuhi kebutuhan energi mereka (Kurniaji, 2015).

\section{METODOLOGI PENELITIAN}

\subsection{Waktu dan Tempat Penelitian}

Penelitian ini dilaksanakan pada tanggal 09 Maret s.d. 26 Maret 2020 di Laboratorium Pengujian Air, Tanah, Debu dan Batuan PT Bukit Asam, Tbk.

\subsection{Teknik Pengumpulan Data}

Teknik pengumpulan data yang dilakukan, yaitu :

1. Penelitian langsung

Dilakukan dengan pengambilan sampel air asam tambang langsung ke lapangan, sampel yang diambil merupakan sampel yang free treatment. Lokasi pengambilan sampel ini pada kolam penampung air buangan dari pit 1 Utara Penambangan Banko.

2. Diskusi

Dilakukan dengan cara tanya-jawab dengan pembimbing lapangan dan para analis di laboratorium PT Bukit Asam, Tbk..

3. Studi literatur

Data-data yang diperoleh bersumber dari literatur yang ada di Laboratorium PT Bukit Asam, Tbk. maupun dari beberapa buku, dan jurnal.

\subsection{Skema Penelitian}

Bagain alir penelitian dapat dilihat seperti skema berikut:

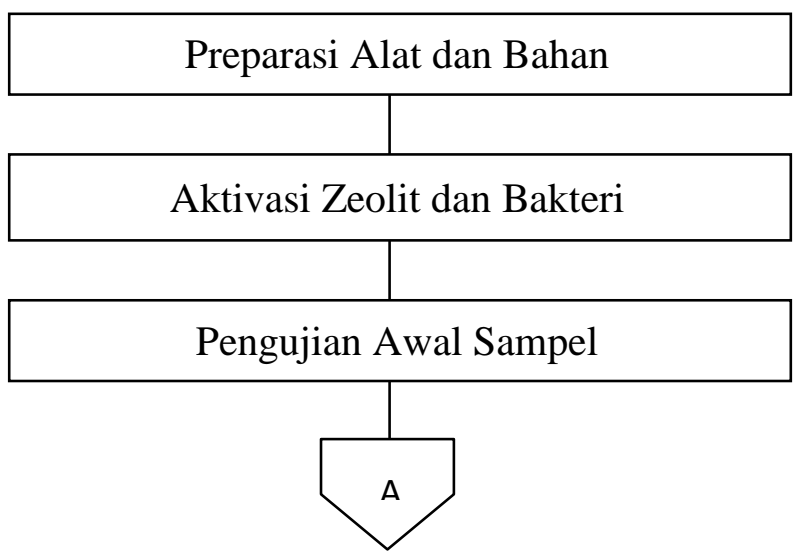

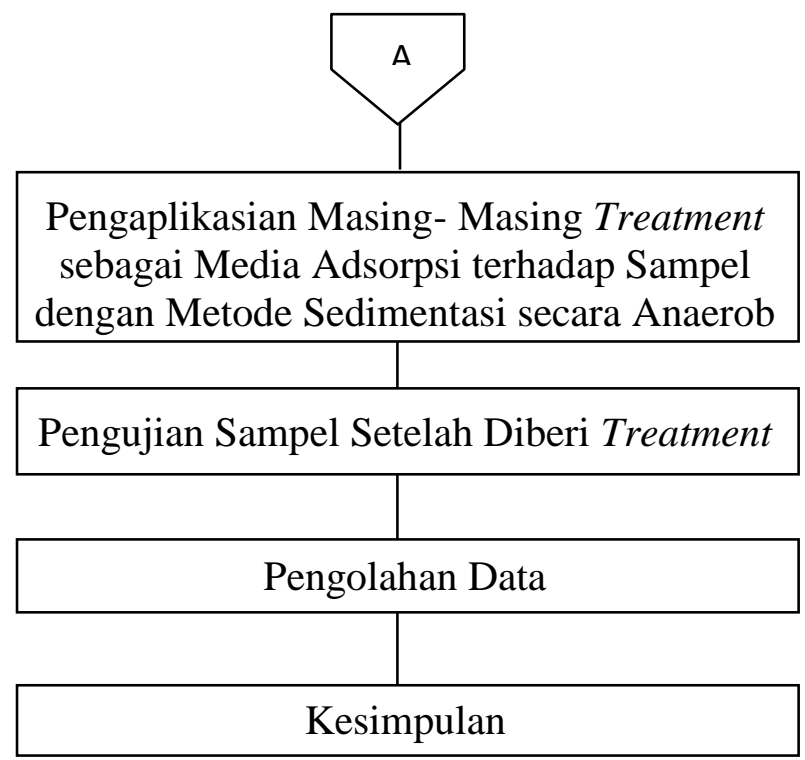

Gambar 3.1 Skema Penelitian

\subsection{Preparasi}

Dalam penelitian ini bahan yang perlu dipreparasi berupa batuan zeolit dan kedua jenis bakteri, nantinya bahan ini akan digunakan untuk perlakuan terhadap sampel air asam tambang. Proses preparasinya, yaitu :

1. Bahan

Bahan yang digunkaan berupa pasir zeolit, BPS (Desulfotomaculum Orientis), BPL (Nitrobacter), dan $\mathrm{HCl}$.

2. Alat

Alat yang digunakan, yaitu: erlemeyer, pipet ukur, oven dan neraca analitik.

3. Zeolit

Aktivasi zeolit dilakukan secara kimia dengan merendam pasir zeolit alam menggunakan larutan campuran akuades dengan $\mathrm{HCl}$ selama 24 jam pada temperatur kamar, sedangkan secara fisika dengan menyaring zeolit yang sudah direndam lalu masukkan ke oven selama 24 jam pada temperatur $80^{\circ} \mathrm{C}$.

4. Bakteri

Untuk aktivasi bakteri dengan cara menimbang sebanyak 10 gram Masing-masing bakteri yang masih berbentuk powder (bubuk) lalu dilarutkan dalam satu liter akuades. Aduk hingga larut, berikutnya diamkan secara anaerob / fermentasikan bakteri selama 3 hari.

5. Perlakuan

Siapkan semua peralatan dan bahan yang akan digunakan. Pada penelitian ini 
menggunakan lima macam treatment yaitu : bakteri BPS, bakteri BPL, zeolit, kombinasi zeolit dengan bakteri BPS, dan kombinasi zeolit dengan bakteri BPL. Disini penggunaan bakteri sebanyak $5 \mathrm{ml}$ dan zeolit sebanyak 5 gram serta sampel sebanyak $500 \mathrm{ml}$. Setelah selesai, diamkan sampel yang telah diberi treatment selama lima hari pengujian. Setelah lima hari analisa sampel menggunakan parameter uji $\mathrm{pH}$, TSS, logam $\mathrm{Fe}$, dan logam Mn.

\section{HASIL DAN PEMBAHASAN}

Hasil pengujian awal terhadap sampel sebelum mengalami perlakuan dengan zeolit dan bakteri hasilnya sebagai berikut :

Tabel 4.1 Hasil Pengujian Awal Sampel

\begin{tabular}{|c|l|c|c|c|}
\hline No. & Analisa & Hasil & $\begin{array}{c}\text { Baku } \\
\text { Mutu (*) }\end{array}$ & Satuan \\
\hline 1. & pH & 2,98 & $6,0-9,0$ & - \\
\hline 2. & TSS & 3 & 300 & $\mathrm{mg} / \mathrm{l}$ \\
\hline 3. & $\mathrm{Fe}$ & 1,7664 & 7,0 & $\mathrm{mg} / \mathrm{l}$ \\
\hline 4. & $\mathrm{Mn}$ & 9,4931 & 4,0 & $\mathrm{mg} / \mathrm{l}$ \\
\hline
\end{tabular}

* Kepmen LH No. 113 Tahun 2003

Tabel 4.2 Hasil Pengujian Sampel Setelah 5 Hari Treatment

\begin{tabular}{|c|c|c|c|c|}
\hline \multirow{2}{*}{ Treatment } & \multicolumn{4}{|c|}{} \\
\cline { 2 - 5 } & $\mathrm{pH}$ & $\begin{array}{c}\mathrm{TTS} \\
(\mathrm{mg} / \mathrm{l})\end{array}$ & $\begin{array}{c}\mathrm{Fe} \\
(\mathrm{mg} / \mathrm{l})\end{array}$ & $\begin{array}{c}\mathrm{Mn} \\
(\mathrm{mg} / \mathrm{l})\end{array}$ \\
\hline BPS & 6,28 & 2 & 1,138 & 8,330 \\
\hline BPL & 3,37 & 1 & 1,108 & 7,628 \\
\hline $\begin{array}{c}\text { BPS dan } \\
\text { Zeolit }\end{array}$ & 5,72 & 1 & 0,192 & 5,672 \\
\hline $\begin{array}{c}\text { BPL dan } \\
\text { Zeolit }\end{array}$ & 4,75 & 1 & 0,673 & 6,171 \\
\hline Zeolit & 5,20 & 1 & 0,304 & 5,281 \\
\hline
\end{tabular}

Dari penelitian yang telah dilakukan dapat disimpulkan bahwa semua perlakuan dapat meningkatkan nilai $\mathrm{pH}$ dari sampel. Diantara perlakuan, Bakteri BPS lebih efektif dalam peningkatan nilai $\mathrm{pH}$ sampel, yang mana dengan menggunakan bakteri BPS sampel yang $\mathrm{pH}$ awalnya 2,98 menjadi 6,28 sehingga dapat dikatakan $\mathrm{pH}$ nya memenuhi batas baku mutu air limbah pertambangan. Perlakuan menggunakan zeolit juga menghasilkan peningkatan $\mathrm{pH}$ yang cukup baik dari $\mathrm{pH} 2,98$ menjadi 5,20. Akan tetapi bila bakteri BPS digabung dengan zeolit kinerja dari bakteri BPS menjadi menurun, hal ini dapat disebabkan oleh faktor pengotor dari zeolit sendiri, atau bakteri BPS menempel pada poripori zeolit sehingga penyerapan menjadi terhambat. Peningkatan $\mathrm{pH}$ perairan ini dapat disebabkan oleh proses reduksi sulfat menjadi sulfida dihasilkan bikarbonat $\left(\mathrm{HCO}_{3}\right)$ yang menyumbang alkalinitas pada perairan (Warkentin, 1994).

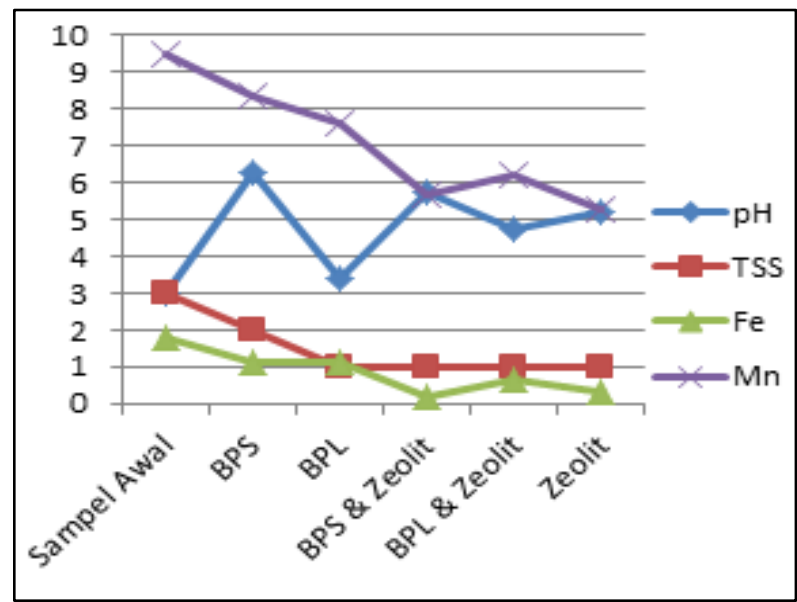

Gambar 4.1. Hasil Pengujian Sampel Setelah 5 Hari Treatment

Untuk Parameter pengujian TSS disimpulkan bahwa semua perlakuan dapat menurunkan kandungan TSS di dalam Air asam tambang. Nilai TSS yang awalnya $3 \mathrm{mg} / \mathrm{l}$ menjadi $1 \mathrm{mg} / \mathrm{l}$, kecuali penggunaan bakteri BPS penurunannya hanya 1 angka saja yaitu menjadi $2 \mathrm{mg} / \mathrm{l}$. Dapat diketahui bahwa zeolit mampu menyerap kotoran-kotoran yang terdapat didalam sampel tersebut melalui poriporinya, begitu juga dengan bakteri BPL yang sifatnya dapat menguraikan limbah organik didalam air sehingga padatan yang terdapat didalamnya menjadi berkurang bahkan hilang.

Hasil penelitian yang telah dilakukan pada parameter pengujian logam Fe terhadap sampel dengan perlakuan menggunakan zeolit ditambah bakteri BPS menunjukkan penurunan kadar Fe yang sangat signifikan. Pada perlakuan tersebut efisiensi pengendapan logam $\mathrm{Fe}$ sebesar $89,11 \%$ dengan kandungan 
awal 1,7664 menjadi 0,1924. Perlakuan yang lainnya juga menujukan penurunan yang signifikan, seperti perlakuan dengan bakteri BPS efisiensi pengendapannya sebesar $35,55 \%$, bakteri BPL sebesar 37,36\%, bakteri BPL ditambah zeolit sebesar $61,90 \%$ dan zeolit sebesar 82,79\%. Dari hasil tersebut dapat disimpulkan bahwa kinerja batuan zeolit sangat baik dalam mereduksi dan menyerap kandungan Fe didalam air asam tambang.

Dalam penelitian ini perlakuan menggunakan zeolit merupakan cara yang paling efektif dalam menurunkan kandungan logam Mn di dalam sampel dibandingankan dengan perlakuan lainnya, yang mana efisiensi pengendapannya sebesar $44,37 \%$ dengan kandungan awal 9,4931 menjadi 5,2813. Perlakuan menggunakan bakteri BPS efisiensinya sebesar 12,25\%, bakteri BPL sebesar 19,64\%, bakteri BPS ditambah zeolit sebesar 40,25\%, dan bakteri BPL ditambah zeolit sebesar $35 \%$. Dari hasil yang diperoleh disimpulkan bahwa batuan zeolit sangat cocok digunakan untuk penurunan kandungan logam Mn dibandingkan dengan penggunaan bakteri. Akan tetapi, jika zeolit ditambahkan dengan bakteri kinerja penyerapannya menjadi berkurang hal tersebut bisa terjadi karena bakteri menutupi pori-pori dari zeolit sehingga penyerapannya tidak efektif. Kinerja dari bakteri BPL lebih baik dibandingkan Bakteri BPS dalam hal penurunan kandungan logam. Penurunan konsentrasi logam terlarut disebabkan oleh sulfida yang dihasilkan dalam proses reduksi sulfat bereaksi dengan ion-ion logam terlarut membentuk sulfida logam yang tidak larut.

\section{KESIMPULAN DAN SARAN}

\subsection{Kesimpulan} bahwa :

Dari hasil penelitian dapat disimpulkan

1. Diperolehnya kuliatas air asam tambang yang lebih baik dibandingkan dengan sebelum diberikan treatment.

2. Diketahui bahwa masing-masing treatment dapat memberikan tingkat kinerja dan pengaruh yang berbeda pada setiap parameter ujinya.
3. Diantara lima macam treatment yang telah digunakan dapat diketahui bahwa treatment menggunakan kombinasi bakteri pereduksi sulfat dan zeolit paling efektif untuk digunakan, dimana hasil skoring penilaiannya dalam setiap parameter uji memiliki nilai paling tinggi.

\section{DAFTAR PUSTAKA}

Febrina, Laila. 2014. Studi Penurunan Kadar Besi (Fe) Dan Mangan (Mn) Dalam Air Tanah Menggunakan Saringan Keramik. Jurnal Fakultas Teknik Universitas Muhammadiyah Jakarta. Volume VII No. 1

Gautama Rudy Sayoga. 2014. Pembentukan, Pengendalian dan Pengelolaan Air Asam Tambang. Bandung : ITB

Hanafiah, dkk. 2018. Uji Potensi Isolat Bakteri Pereduksi Sulfat (BPS) Terhadap Perubahan Kemasaman Tanah Sulfat Masam Dan Pertumbuhan Tanaman Jagung Dengan Kondisi Air Tanah Berbeda Di Rumah Kaca. Jurnal Agroekoteknologi FP USU. Volume 6 No. 3

Hidayat, Luthfi. 2017. Pengelolaan Lingkungan Areal Tambang Batubara. Jurnal ADHUM. Volume VII No. 1

Nurisman, Enggal et.al. 2012. Studi Terhadap Dosis Penggunaan Kapur Tohor ( $\mathrm{CaO}$ ) pada Proses Pengolahan Air Asam Tambang pada Kolam Pengendap Lumpur Tambang Air Laya PT Bukit Asam, Tbk.. Jurnal Teknik Patra Akademika Politeknik Akamigas Palembang. Edisi Kelima

Putra, Sinly Evan. 2007. Zeolit Sebagai Mineral Serba Guna. (file:///E:/LA/zeolit\%20dan\%20bentonit/Zeolit $\% 20$ sebagai\%20Mineral\%20Serba\%20Guna\% 20Chemistry.Org\%20_\%20Situs\%20Kimia\%2 OIndonesia\%20.htm). Diakses tanggal 25 Maret 2020 
Rudy, S.P. 2012. Pengelolaan Air Asam Tambang. Jurnal Teknologi Mineral dan Batubara. Vol.15, No.02 :78-90.

SNI 6989-4-2009. 2009. Cara Uji Besi (Fe) dengan Spektrofotometri Serapan Atom (SSA). Badan Standarisasi Nasional : Bandung.

SNI 6989-5-2009. 2009. Cara Uji Mangan (Mn) dengan Spektrofotometri Serapan Atom (SSA). Badan Standarisasi Nasional : Bandung.

SNI 6989-3-2019. 2019. Cara Uji Padatan Tersuspensi Total (Total Suspended Solid) secara Gravimetri. Badan Standarisasi Nasional : Bandung.

SNI 6989-11-2019. 2019. Cara Uji Derajat Keasaman $(p H)$ dengan Menggunakan Alat Uji pH Meter. Badan Standarisasi Nasional : Bandung. 
P-ISSN: 2089-5925 E-ISSN: 2621-9328

Antrant

Jurnal Teknik Patra Akademika

PATA

Arademika

Volume 11 No. 01 Juli 2020 